\title{
Factors Impacting on the Selection of Third Party Logistics Provider
}

\author{
Tu Van Binh \\ University of Economics Ho Chi Minh City and CFVG, Ho Chi Minh City, Vietnam \\ Nguyen Thanh Kien \\ CFVG, Ho Chi Minh City,Vietnam
}

\begin{abstract}
With 200 firms interviewed, who use logistics services, interesting findings show that firm with different sizes have different demands toward logistics services. There are key factors impact on firm's 3PL selection, e.g. cost of service, reputation, operation performance, and long-term relationship, in which they are mostly depended on cost of service. This means that they agree with the best choice depended on cost of service of 3PL providers. Reputation is concerned as the second ranking, operation performance of 3PL provider as the third ranking and long-term relationship as the fourth ranking. Unlucky, there is no evidence to confirm financial performance of 3PL providers is considered by firm toward selection. This case is not surprised, because financial performance of the provider is internal information, it isn't easy to let its customer know that.
\end{abstract}

Keywords: third party logistics, enterprises, suppliers, Vietnam

\section{Background}

Since 1990 till now, Vietnam has attained fast economic growth. The economics has been changing from a primary agriculture-based to one emphasizing industry and export-oriented activity. GDP of Vietnam has been growth stabilized at 6-8 percent per year during 1990-2015 ${ }^{1}$. In addition, Vietnam has paid more attention to integrating with the global economy, such as, being a member of organizations of WTO, ASEAN, and TPP, also attracting more FDI flow into as well as the growth of domestic enterprises. As a result, the demand for a robust transportation and logistics sector will be booming in the upcoming year.

Although logistics has been growing very much in the world, it isn't popular in Vietnam. This is not surprised much, because Vietnam is just in process of integration and regularize legitimacy to meet the international requirements.

There is a general perception among logistics operators and users that ports in Vietnam are not well suited to cater for modern maritime transport due to existing physical constraints. This impression is translated in the urgency to further support deep-sea port development and improves port capability. Sea transport is the most

Tu Van Binh, Vice Dean of Graduate School_-University of Economics Ho Chi Minh City and Professor at CFVG-European Excellence in Management Education, Ho Chi Minh City, Vietnam.

Nguyen Thanh Kien, CFVG-European Excellence in Management Education, Ho Chi Minh City, Vietnam.

Correspondence concerning this article should be addressed to Tu Van Binh, CFVG, 3/2 Street, District 10, Ho Chi Minh City, Vietnam.

${ }^{1}$ Vietnam General Statistics Office (GSO). 
important mode for the carriage of imports and exports of Vietnam. However, these, such as ports and vessels, are still insufficient and in need of further development (Thai \& Grewal, 2005).

As the above mentioned, this paper is conducted to determine key factors and they will be measured how much impacting on firms' selection to 3PL service provider in Hachiman city and surrounding area. Then, based on the important level of the factors found from the user view point, the paper is going to discuss some managerial implication for 3PL services provider to improve capacity of logistics services.

\section{The Literature Framework}

With the growth in globalization, the supply chains are going to be more complex. International logistics involved more transportation and distribution. Due to the difference of customs procedure, infrastructure, and regulations between country and country, the demand of expertise third-party logistics (TPL) has been increasing also. According to Knemeyer, Corsi, and Murphy (2003), TPL referred to as logistics resourcing and used as a label for traditional "arm's length" sourcing of transportation and/or warehousing, whereas in other instances the term is used to describe a outsourcing of a more complex character that can encompass the entire logistics process (Marasco, 2008). Hertz and Alfredsson (2003) divided 3PL into four types: (i) Standard 3PL providers; (ii) Service developers; (iii) Customer adapters; (iv) Customer developer. Meanwhile, Muller (1993) suggested the four types of 3PL provider: asset-based vendors, management-based vendors, integrated vendors, and administration-based vendors.

According to Farahani, Rezapour, and Kardar (2011), there are five types of party logistics, e.g. first party logistics (1PL), second party logistics (2PL), third party logistics (3PL), fourth party logistics (4PL), fifth party logistics (5PL). However, 3PL is a common term and a complex process, which the logistics users have to consider multidimensional with both tangible and intangible criteria. The determinant of a perfect set of selection criteria seems to be a tough problem with the assessors. Some criteria are common for all case, while others are built depending on specific customer needs. In common, main selection criteria can categorize into some groups like: cost, financial performance, operational performance, reputation of the 3PL, and long-term relationship.

As mentioned above, five types of party logistics have differences in concept. Of which, at first, 1PL means that cargo owners themselves organized and carried out the logistics activities to meet their own needs. Under this form, the customer must invest in transport, warehousing, information systems, management and labor to operate the logistics activities. Secondly, 2PL that it provides its own assets as truck owners, warehouse operators. This category includes the carriers by sea, road, aviation, warehousing, customs clearance, and payment intermediaries. Thirdly, 3PL means that its provider performs logistics services on behalf of another company and provides the management skills along with the physical assets, labor and systems technology to provide professional logistics services. In addition, 3PL can give services of transportation, warehousing, pool distribution, management consulting, logistics optimization, freight forwarding, and transportation management. Fourthly, 4PL means that it integrates all companies involved along the supply chain and is the planning, steering, and controlling of all logistics procedures. Fifthly, 5PL is a concept of design and restructure of the supply chain. Operations of 4PL and 3PL are to provide integrated information system to ensure information flow continuously and increase the ability to control entire supply chain, while managing and coordinating activities of the 3PL and 4PL through information related to supply and demand on the market of electronic logistics services.

As arguments of Hertz and Aldredsson (2003), 3PL is classified into four types: (i) service developer; (ii) 
Customer developer; (iii) Standard TPL provider; (iv) Customer adapter. However, according to (Muller, 1993), there are four types of 3PL provider: (i) Asset-based vendors: Companies offer logistics services through their physical assets like warehousing, truck, vessels, etc.; (ii) Management-based vendors: Companies don’t own physical assets. They provide integrate logistics system management services through information structure or traffic management operation; (iii) Integrated vendors: Companies provide services through both their physical asset and also renting services from other vendors to meet requirements of their clients; (iv) Administration-based vendors: Companies generally provide administrative services like freight payment.

Based on another study of Dapiran, Lieb, and Rabinovic (1996) on 84 users of 3PL in Australia, cost is the most important selection factor. Then, services, coverage capacity, perceived competence, personal knowledge of the contractor, references and experience, which experience in project management and new systems implementation are extra important factors. Bhatnagar, Sohal, and Millen (1999) conducted a study on 126 companies in Singapore, the result pointed out that the most important criteria in selecting 3PL are cost and service quality. The other factors are reputation, range of services, and experiences. Boyson, Corsi, Dresener, and Rabinovic (1999) with a study on 463 firms in US, proved that the most important selection criteria belong to price, customer service, and financial stability. In addition, information system and technology capabilities, general reputation, creativity in problem solving, reputation for problem solving, the compatibility of cultures, asset ownership, international scope, relationship with the user, and the human resources policy of the 3PL, are also taken into account.

In Vietnam, based on the logistics survey in 2008 by the government, the logistics user ranks the important level of selection criteria as following: service quality, price, continuous improving, experience of 3PL, geographic coverage, ability to offer more service, quality human resources, compatibility in culture, IT capacity, type of companies, flexibility in services. Therefore, there are so much criteria for assessing a quality 3PL provider. The evaluation depends on the viewpoint of the assessor. The view point of the provider will be different from the view point of the user and characteristics of the user's business.

Along with the increasing of globalization, 3PL in particular is paid more attention to business man as well as researchers. According to Aguezzoul (2012), there are 67 papers cited on 3PL selection which have been published during 1994 to 2013. Meade and Sarkis (2002) developed conceptual model for selecting and evaluating third party reverse logistics providers, they found factors of time, quality, and cost and flexibility are the most important. Hwang et al. (2005) develop the model of the supplier selection and planning based on the major supplier selection indicators, such as serviceability, inventory rotation rate, lead time, customer satisfaction, market share.

With what mentioned above, arguments are presented that 3PL providers perform logistics services on behalf of another company, 3PL provides the management skills along with the physical assets, labor and systems technology to provide professional logistics services, relieving companies of the responsibility of performing these services themselves. As a result, the model proposed in this paper is depicted in Figure 1, its factors are argued as the following.

Cost of service: It refers to transportation price, payment terms, non-official cost or extra cost during transactions, cost saving after optimization and other handling cost.

Reputation of the 3PL: Brand name endorses the quality, reliability, customer service level, customer satisfaction, and contract fulfillment. A brand name lures the shipper to step in to begin long-term relationship. Reputation of the 3PL services providers also guarantees sound financial position, which plays an important 
role in inviting shippers for its selection. In the study of large American manufacturers, the reputation was one of the additional criteria, which was considered by many 3PL users (Lieb \& Randall, 1996). In this study, reputation of the 3PL factor is connected to geographic spread, experience as a 3PL provider, specific industry focus, and range of services provider.

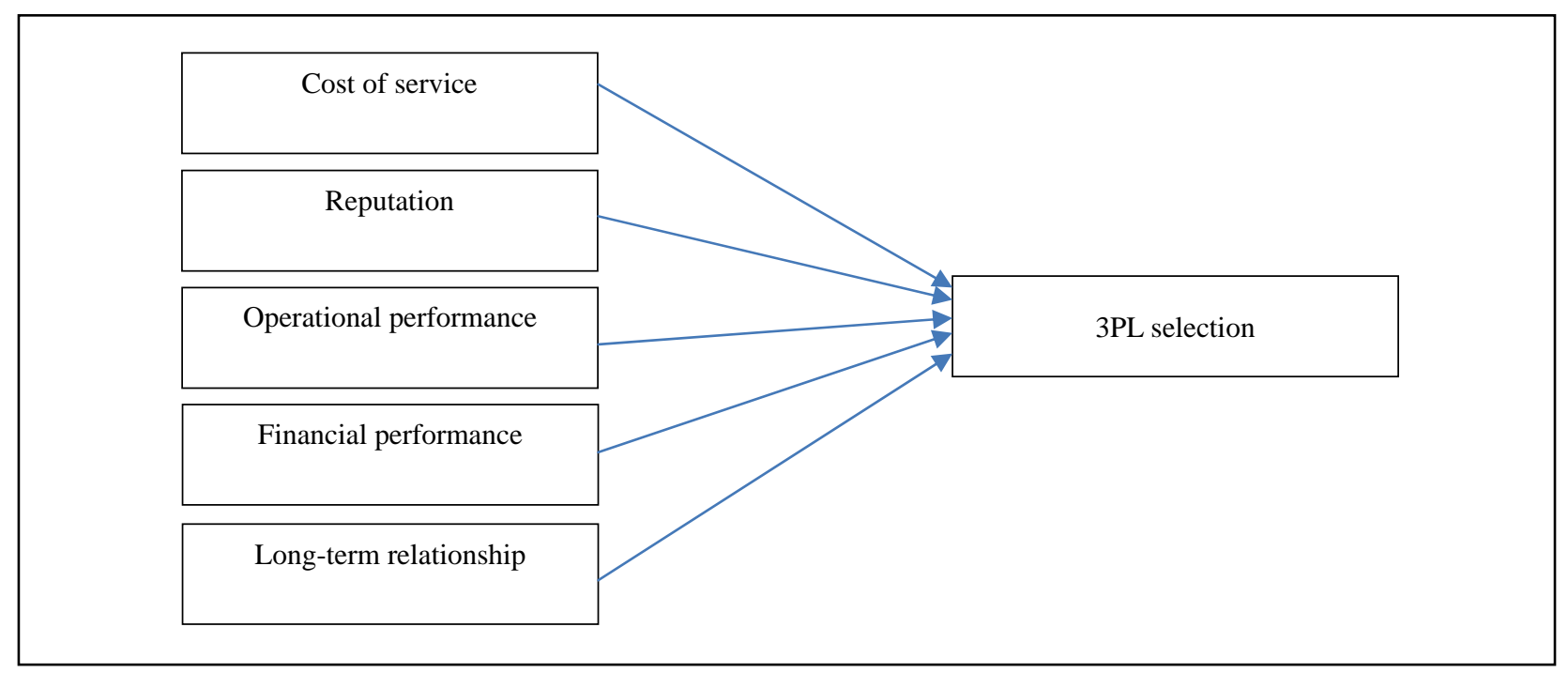

Figure 1. Proposed model with five factors.

Operational performance: It assures effectiveness and efficiency of the 3PL services provider. High operational performance improves the business relations. Clear-cut goal in terms of quantitatively measurable and meaningful performance boosts long-term relationship (Bowersox \& Daugherty, 1987). Higher operational performance eases up operation and configuration. It also enhances performance-measuring capability, fault diagnosing, capability, ability to resolve a potential problems, detailed accounting information, system security, responsiveness and confidentiality of sensitive data (Spencer et al., 1994). It also enables 3PL services provider to provide an operational status report to the shipper consistently. In short, there are global capability, service quality, IT capability, delivery performance, satisfaction of employees, and continuing improvement represented.

Financial performance: Financial performance of the 3PL guarantee for continuity of service flexibility in billing and payment, financial stability, ability of advanced payment, net working capital and size, quality of fix assets.

Long-term relationship: This factor includes information sharing and mutual trust, compatibility with users, willingness to use logistics manpower, risk management, and gain sharing.

Based on the proposed model, there are five hypotheses considered as follows:

H1: There is a significant impact of cost of service on 3PL selection.

H2: There is a significant impact of reputation of the 3PL on 3PL selection.

H3: There is a significant impact of operational performance on 3PL selection.

H4: There is a significant impact of financial performance on 3PL selection.

H5: There is a significant impact of long-term relationship on 3PL selection.

\section{Overview of Logistics in Vietnam}


In Vietnam, logistics was developed, but not a formal concept. It means there is no official authority with total responsibility over logistics. There exist definition of logistics services in the 2005 Commerce Law as well as in the Decree 140/2007 ND-CP (5/9/2007):

Logistics services means a commercial activity whereby a business entity organizes the implementation of one or more tasks, including receiving goods; arranging transportation, warehousing, storage, completion of customs formalities and other documentation procedures; providing consultancy to clients; packing goods and labelling them with their codes, and goods delivery or other services relating to goods in accordance with an agreement with clients in order to enjoy remuneration.

According to the World Bank's Trade and Transport Facilitation Assessment (World Bank, 2010), the logistics expenditure in Vietnam is estimated at about 20\% of GDP. In 2014 it increased to about 23\% of GDP. By a comparison with countries like Singapore, Malaysia, Thailand, and China, logistics cost in Vietnam is so much higher (Figure 2).

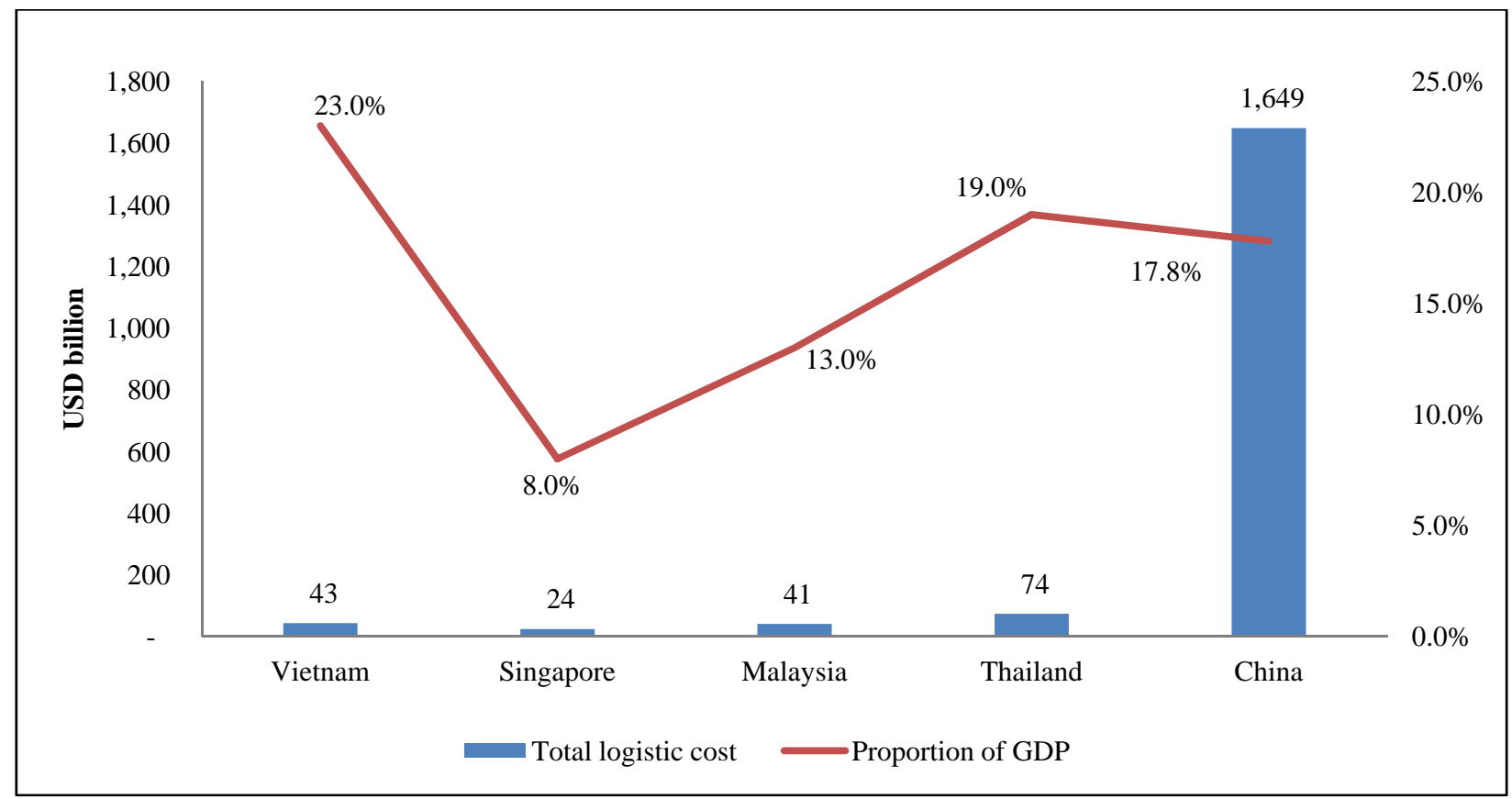

Figure 2. Logistics cost in Vietnam versus other countries in 2014. Source: StoxPlus.

Banomyong (2005) argued that Vietnamese logistics system can be based on four strategic dimensions, recognized as the core factors of a national logistics system to create a holistic and coherent structure. Therefore, the national logistics system is composed of (i) transport and logistics infrastructure, (ii) the institutional and regulatory framework, (iii) service providers, and (iv) logistics service users.

The availability and quality of infrastructure is one of the key factors in determining the logistics environment of a country. In general, it can be observed that in terms of both infrastructure and services, each individual mode of transport in Vietnam suffers from limited capacity and capability. Nevertheless, there are important modal differences reflecting the degree to which they can contribute to the development of a national logistics system and logistics market.

There are more than 200 foreign shipping lines operating liner and container services to Vietnam both directly and indirectly through feeder networks with feeder containers vessels that link Vietnam to nearby 
hub-ports such as Singapore, Hong Kong, or Kaohsiung, where containers are trans-shipped to worldwide destinations by mother vessels.

In terms of logistics, there is a general administrative fragmentation in Vietnam which is reflected in a regulatory environment that at times is unclear if not contradictory. This applies to provincial, national regulations and to some extent also to the process of implementation of regional and multilateral agreements.

In fact, there have not been accurate data about the number of enterprises that provide logistics services in Vietnam yet. According to Vietnam Freight Forwarders Association (VIFFAS), until November 2012 there are approximately 1,200 freight forwarders in Vietnam. In term of capital, logistics firms in Vietnam are categorized into three main groups, such as logistics firms with $100 \%$ foreign direct investment (FDI), companies or joint ventures, state- and private-owned enterprises. Accordingly, firms with $100 \%$ FDI and joint ventures, focus on multinational customers, having full perceptional about logistics and needing integrated, end-to-end logistics services. SOEs are the group that captures almost all domestic transportation and forwarding services. Their customers are quite diversified. POEs are the group, who has the most potential for growth in the future. They focus on customer with similar position.

Most of logistics companies in Vietnam are small- and medium-sized private companies, while SOEs often lack skills, technology, and capacity to provide value-added logistics and multimodal transport services. However, SOEs have more experiences, huge capital, well-equipped facilities, and large warehouse.

All local logistics service providers (LSP) offer domestic container services for inland movement of goods. Service quality of the local trucking industry is still considered rather low and at times unpredictable. Tracking and tracing are still uncommon in road haulage. In other words, it has not been considered as an essential success factor in enhancing Vietnamese LSP's performance. The monitoring of freight flows or the development of track and trace capability for cargo would be beneficial to Vietnamese traders and manufacturers but currently not many logistics service providers in Vietnam are able to offer such a service.

In general, Vietnamese logistics companies have faced with limited services and lack of international competitiveness. As a result, it is difficult for Vietnam's LSP to provide competitive logistics service even within the domestic market, not to speak of in international or global markets.

In summary, the quality of logistics services provided by Vietnam's local LSPs is still low, with limited ability to compete with foreign logistics service suppliers. At present, domestic operators tend to provide more specific elements of the chain than integrated services. Additionally, Vietnamese trading companies are generally not aware of the importance of managing logistics and the supply chain as well as the potential benefits associated therewith Banomyong (2005). Logistics system capability is subject to constraints in all of the key logistics dimensions. Local logistics service providers still suffer some limited capability and would require higher level of technical know-how in order to better compete in an increasing liberalized logistics market, and need to understand the benefit of outsourcing and the competitive position offered when in partnership with LSP.

\section{Data Collection Analysis}

Data used in the paper are mainly quantitative methods conducted on respondents who are logistics users located in Ho Chi Minh City. The questionnaire designed is based on qualitative research conducted on 10 respondents, who are experts of the sector, including logistics providers and users. With quantitative research, there are 223 respondents interviewed. However 200 questionnaires are sufficient, due to the fact that 23 
questionnaires are unsatisfied answers and excluded. All respondents are directly interviewed by face to face, the place to take interviewing is main ports in Ho Chi Minh City, e.g. Cat Lai, ICD Phuoc Long, VICT, Ben Nghe, Lotus. The research was conducted during September to December 2015. Measures of items belong factors proposed in the model are five point scale, with 1 being unlikely, 5 being likely. Items developed is based on literature review, its information is mentioned in Table 1.

As resulted in Table 2, the sample distributed in the type of limited company accounts for the highest share of $40 \%$, next as joint stock one with $27.5 \%$, POE with $15 \%$. Although SOE plays an important role in the economy system of Vietnam in general, its logistics business just occupies a few contribution.

Table 1

Items Belong Factors

\begin{tabular}{|c|c|c|c|}
\hline No. & Code & Items & Source \\
\hline I & CS & Cost of service & \multirow{8}{*}{$\begin{array}{l}\text { Bagchi and Virum (1998) } \\
\text { Meade and Sarkis (2002) }\end{array}$} \\
\hline 1 & CS1 & Transportation price & \\
\hline 2 & CS2 & Term of payment & \\
\hline 3 & CS3 & Non official cost or extra cost & \\
\hline 4 & CS4 & Cost saving due to optimizing transaction & \\
\hline 5 & CS5 & Handling cost & \\
\hline II & $\mathrm{RP}$ & Reputation of the 3PL & \\
\hline 6 & REP1 & Geographic spread & \\
\hline 7 & REP2 & Experience as a $3 \mathrm{PL}$ & \multirow{6}{*}{$\begin{array}{l}\text { Lynch (2000), Thompson } \\
\text { (1996) }\end{array}$} \\
\hline 8 & REP3 & Focus on specific industry & \\
\hline 9 & REP4 & Range of services provider & \\
\hline III & $\mathrm{OP}$ & Operational performance & \\
\hline 10 & OP1 & Quality of service & \\
\hline 11 & OP2 & IT capability & \\
\hline 12 & OP3 & Delivery performance & \multirow{7}{*}{$\begin{array}{l}\text { Langely et al. (2002) } \\
\text { Tam and Tummala (2001) }\end{array}$} \\
\hline 13 & OP4 & Employee satisfaction & \\
\hline 14 & OP5 & Continuing improvement & \\
\hline 15 & OP6 & Global capability & \\
\hline IV & FP & Financial performance & \\
\hline 16 & FP1 & Flexibility in billing and payment & \\
\hline 17 & FP2 & Financial stability & \\
\hline 18 & FP3 & Ability of advance payment & \multirow{2}{*}{$\begin{array}{l}\text { Anderson and Norman (2002) } \\
\text { Boyson et al. (1999) }\end{array}$} \\
\hline 19 & FP4 & Net working capital & \\
\hline 20 & FP5 & Size and quality of fix asset & \multirow{9}{*}{$\begin{array}{l}\text { Lynch (2000) } \\
\text { Boyson et al. (1999) }\end{array}$} \\
\hline V & LR & Long-term relationship & \\
\hline 21 & LR1 & Information sharing and mutual trust & \\
\hline 22 & LR2 & Compatibility with the user & \\
\hline 23 & LR3 & Willingness to use logistics manpower & \\
\hline 24 & LR4 & Risk management & \\
\hline 25 & LR5 & Gain sharing & \\
\hline & OS & Overall Assessment & \\
\hline 26 & OS1 & After considering all above items, I chose the current 3PL service provider. & \\
\hline
\end{tabular}


Table 2

Type of Logistics Providers

\begin{tabular}{lll}
\hline Type of company & Frequency & Percentage \\
\hline Limited company & 80 & $40.0 \%$ \\
Private owned enterprise (POE) & 30 & $15.0 \%$ \\
Joint stock company & 55 & $27.5 \%$ \\
State owned enterprise (SOE) & 20 & $10.0 \%$ \\
Foreign investment company & 10 & $5.00 \%$ \\
Other & 5 & $2.50 \%$ \\
Total & 200 & $100 \%$ \\
\hline
\end{tabular}

Source: Own survey.

The firm size of logistics users is mainly distributed in the range of under 30 employees (39\%) and from 30 to 100 employees (31\%) (Table 3). As a result, mostly logistics users are mainly small- and medium-sized enterprises (SMEs). That means that logistics service is popular for firms with size of less than 100 employees. A few share is belonging to the firm size with rank of 100 to 300 employees accounting for $27.5 \%$ and over 300 employee occupying $2.5 \%$. Service usage of firms is mainly concentrated on domestic transportation and international transportation, which is depended on business type and size of firms (Table 4).

Table 3

Size of Firms Interviewed

\begin{tabular}{lll}
\hline Size of firm & Frequency & Percentage \\
\hline Under 30 employees & 78 & $39.00 \%$ \\
From 30 to 100 employees & 62 & $31.00 \%$ \\
From 100 to 300 employees & 53 & $27.50 \%$ \\
Over 300 employees & 5 & $2.5 \%$ \\
Total & 200 & 100 \\
\hline
\end{tabular}

Source: Own survey.

Table 4

Logistics Service Usage of Firm

\begin{tabular}{lll}
\hline Service usage & Frequency & Percentage \\
\hline Domestics transportation & 184 & $92.00 \%$ \\
International transportation & 178 & $89.00 \%$ \\
Warehousing & 140 & $70.00 \%$ \\
Customs clearance and brokerage & 136 & $68.00 \%$ \\
Forwarding & 120 & $60.00 \%$ \\
Shipment consolidation & 80 & $40.00 \%$ \\
Product labeling, packaging, knitting, assembly & 66 & $33.00 \%$ \\
Transportation management & 50 & $25.00 \%$ \\
Reverse logistics & 50 & $25.00 \%$ \\
Cross-docking & 50 & $25.00 \%$ \\
Freight auditing and payment & 36 & $18.00 \%$ \\
Fleet management & 30 & $15.00 \%$ \\
Supply chain consultancy & 26 & $13.00 \%$ \\
Order entry, processing and fulfillment & 24 & $12.00 \%$ \\
Customer services & 10 & $5.00 \%$ \\
LLP/4PL services & 6 & $3.00 \%$ \\
\hline
\end{tabular}




\section{Reliability Test}

Cost of service. Cronbach's Alpha test is used to test all items mentioned previously. As shown in Table 5, items are sufficient and Cronbach's Alpha of factors (e.g. cost of service, reputation, operational performance, financial performance, and long-term relationship) are reliable, because their values are greater than 0.7 (Hair, Black, Babin, \& Anderson, 2010).

Because items above are sufficient for reliability, all of them are used in Exploratory Factor Analysis (EFA). Accordingly, the result of EFA meets condition of method with indicators of KMO value $=0.789$ $(>0.5)$, significant level $=0.000$, all of factor loading $>0.5$, percentage of total variance explained of five factors $=73.76 \%>60 \%$.

Table 5

Reliability Test of Items Belong Factors

\begin{tabular}{|c|c|c|c|c|}
\hline Items & $\begin{array}{l}\text { Sale mean if item } \\
\text { deleted }\end{array}$ & $\begin{array}{l}\text { Scale variance if } \\
\text { item deleted }\end{array}$ & $\begin{array}{l}\text { Corrected item-total } \\
\text { correction }\end{array}$ & $\begin{array}{l}\text { Cronbach's Alpha } \\
\text { if item deleted }\end{array}$ \\
\hline Cost of service & \multicolumn{4}{|c|}{ Cronbach’s Alpha = 0.886} \\
\hline Transportation price & 15.66 & 6.850 & 0.782 & 0.848 \\
\hline Payment terms & 15.44 & 7.293 & 0.706 & 0.866 \\
\hline Non official cost or extra cost & 15.54 & 6.783 & 0.763 & 0.852 \\
\hline Cost saving due to optimizing transportations & 15.52 & 6.673 & 0.694 & 0.872 \\
\hline Handling cost & 15.48 & 7.366 & 0.692 & 0.869 \\
\hline Reputation & \multicolumn{4}{|c|}{ Cronbach’s Alpha = 0.885} \\
\hline Geographic spread & 12.30 & 2.408 & 0.805 & 0.831 \\
\hline Experience as a $3 \mathrm{PL}$ & 12.33 & 2.835 & 0.694 & 0.873 \\
\hline Focus on specific industry & 12.19 & 3.006 & 0.702 & 0.869 \\
\hline Range of service provider & 12.41 & 2.835 & 0.812 & 0.831 \\
\hline Operation performance & \multicolumn{4}{|c|}{ Cronbach’s Alpha = 0.897} \\
\hline Global capability & 19.03 & 11.617 & 0.632 & 0.895 \\
\hline Quality of service & 18.79 & 11.466 & 0.707 & 0.882 \\
\hline IT capability & 18.99 & 10.844 & 0.794 & 0.868 \\
\hline Delivery performance & 19.08 & 11.648 & 0.830 & 0.866 \\
\hline Employee satisfaction & 19.18 & 11.746 & 0.731 & 0.878 \\
\hline Continuing improvement & 18.97 & 11.984 & 0.672 & 0.887 \\
\hline Financial performance & \multicolumn{4}{|c|}{ Cronbach’s Alpha = 0.925} \\
\hline Flexibility in billing and payment & 15.05 & 7.953 & 0.777 & 0.913 \\
\hline Financial stability & 15.23 & 7.462 & 0.804 & 0.909 \\
\hline Financial of advanced payment & 15.20 & 7.940 & 0.845 & 0.900 \\
\hline Networking capital & 15.00 & 7.598 & 0.812 & 0.906 \\
\hline Size and quality of fix asset & 15.13 & 8.827 & 0.833 & 0.909 \\
\hline Long-term relationship & \multicolumn{4}{|c|}{ Cronbach’s Alpha = 0.835} \\
\hline Information sharing and mutual trust & 15.97 & 5.300 & 0.638 & 0.801 \\
\hline Capability with the user & 15.75 & 4.781 & 0.705 & 0.782 \\
\hline Willingness to use logistics manpower & 15.67 & 5.840 & 0.588 & 0.815 \\
\hline Risk management & 15.87 & 5.501 & 0.586 & 0.814 \\
\hline Gain sharing & 15.67 & 5.561 & 0.678 & 0.792 \\
\hline
\end{tabular}


Testing model and hypothesis. Before going to run regression to test hypotheses, evaluation of correlations between five factors (as independent variables) and overall assessment to 3PL provider selection (dependent variable) is shown in Table 6.

Considering the linear correlation between the independent variables and dependent variable, all five independent factors are accepted to conduct in testing model. Continuously, regression model is employed with Enter method to consider the weight of antecedent contributing to overall assessment 3PL provider selection. The coefficient of determination, $R$ squared $\left(R^{2}=0.712\right)$ indicates how well data fit a statistical model. It presents variation in 3PL selection of firms are explained by $71.2 \%$ of variations in cost of service, reputation of the 3PL, operation performance, financial performance, and long term relationships.

As resulted in Table 7, the factor of financial performance is not significant at any level while other four factors are significant at any level, in which cost of service is the most impact on the firm's selection toward logistics services, next as reputation, operation performance, and long-term relationship.

Table 6

Correlation Between Five Factors and Overall Assessment on 3PL Selection

\begin{tabular}{|c|c|c|c|c|c|c|c|}
\hline \multicolumn{8}{|l|}{ Correlations } \\
\hline & & $\begin{array}{l}\text { Overall } \\
\text { assessment } \\
\text { to logistic } \\
\text { suppliers } \\
\end{array}$ & $\begin{array}{l}\text { Cost of } \\
\text { service }\end{array}$ & $\begin{array}{l}\text { Reputation } \\
\text { of the 3PL }\end{array}$ & $\begin{array}{l}\text { Operation } \\
\text { performance }\end{array}$ & $\begin{array}{l}\text { Financial } \\
\text { performance }\end{array}$ & $\begin{array}{l}\text { Long-term } \\
\text { relationship }\end{array}$ \\
\hline \multirow{2}{*}{$\begin{array}{l}\text { Overall assessment } \\
\text { to logistic suppliers }\end{array}$} & Pearson Correlation & 1 & $0.624^{* *}$ & $0.550^{* *}$ & $0.700^{* *}$ & $0.558^{* *}$ & $0.595^{* *}$ \\
\hline & Sig. (2-tailed) & & 0.000 & 0.000 & 0.000 & 0.000 & 0.000 \\
\hline \multirow{2}{*}{ Cost of service } & Pearson Correlation & $0.624^{* *}$ & 1 & $0.273^{* *}$ & $0.571^{* *}$ & $0.576^{* *}$ & $0.247^{* *}$ \\
\hline & Sig. (2-tailed) & 0.000 & & 0.000 & 0.000 & 0.000 & 0.000 \\
\hline \multirow{2}{*}{$\begin{array}{l}\text { Reputation of } \\
\text { the 3PL }\end{array}$} & Pearson Correlation & $0.550^{* *}$ & $0.273^{* *}$ & 1 & $0.296^{* *}$ & $0.325^{* *}$ & $0.293^{* *}$ \\
\hline & Sig. (2-tailed) & 0.000 & 0.000 & & 0.000 & 0.000 & 0.000 \\
\hline \multirow{2}{*}{$\begin{array}{l}\text { Operation } \\
\text { performance }\end{array}$} & Pearson Correlation & $0.700^{* *}$ & $0.571^{* *}$ & $0.296^{* *}$ & 1 & $0.649^{* *}$ & $0.561^{* *}$ \\
\hline & Sig. (2-tailed) & 0.000 & 0.000 & 0.000 & & 0.000 & 0.000 \\
\hline \multirow{2}{*}{$\begin{array}{l}\text { Financial } \\
\text { performance }\end{array}$} & Pearson Correlation & $0.558^{* *}$ & $0.576^{* *}$ & $0.325^{* *}$ & $0.649^{* *}$ & 1 & $0.357^{* *}$ \\
\hline & Sig. (2-tailed) & 0.000 & 0.000 & 0.000 & 0.000 & & 0.000 \\
\hline \multirow{2}{*}{$\begin{array}{l}\text { Long-term } \\
\text { relationship }\end{array}$} & Pearson Correlation & $0.595^{* *}$ & $0.247^{* *}$ & $0.293^{* *}$ & $0.561^{* *}$ & $0.357^{* *}$ & 1 \\
\hline & Sig. (2-tailed) & 0.000 & 0.000 & 0.000 & 0.000 & 0.000 & \\
\hline
\end{tabular}

Note. ${ }^{* *}$ Correlation is significant at the 0.01 level (2-tailed).

Table 7

Result of Regression

\begin{tabular}{|c|c|c|c|c|c|c|c|}
\hline \multicolumn{8}{|c|}{ Coefficients $^{\mathrm{a}}$} \\
\hline \multirow[t]{2}{*}{ Model 1} & \multicolumn{2}{|c|}{$\begin{array}{l}\text { Unstandardized } \\
\text { coefficients }\end{array}$} & \multirow{2}{*}{$\begin{array}{l}\text { Standardized } \\
\text { coefficients } \\
\text { Beta }\end{array}$} & \multirow[t]{2}{*}{$\mathrm{T}$} & \multirow[t]{2}{*}{ Sig. } & \multicolumn{2}{|c|}{$\begin{array}{c}\text { Collinearity } \\
\text { statistics }\end{array}$} \\
\hline & $\mathrm{B}$ & Std. error & & & & Tolerance & VIF \\
\hline (Constant) & 0.247 & 0.205 & & 1.204 & 0.230 & & \\
\hline CS cost of service & 0.259 & 0.041 & 0.315 & 6.354 & 0.000 & 0.588 & 1.701 \\
\hline REP reputation of the $3 \mathrm{PL}$ & 0.332 & 0.045 & 0.302 & 7.324 & 0.000 & 0.849 & 1.177 \\
\hline OP operation performance & 0.218 & 0.047 & 0.277 & 4.630 & 0.000 & 0.405 & 2.472 \\
\hline FP financial performance & 0.000 & 0.041 & 0.001 & 0.011 & 0.992 & 0.505 & 1.982 \\
\hline LR longterm relationship & 0.257 & 0.044 & 0.273 & 5.805 & 0.000 & 0.656 & 1.525 \\
\hline
\end{tabular}

Note. a. Dependent variable: Assessment overall assessment to logistic suppliers. 
As mentioned previously, there are four hypotheses supported, only the hypothesis of "There is a significant impact of financial performance on 3PL selection" is not supported. Levels of factors impacting on the firm's 3PL selection are ranked in Table 8.

Table 8

Important Level of Factors Influencing Firm Toward 3PL

\begin{tabular}{llll}
\hline Descriptive statistics & & \\
\hline & Mean & Standardized coefficients beta & Level of importance \\
\hline Cost of service & 3.88 & 0.315 & 1 \\
Reputation of the 3PL & 4.04 & 0.302 & 2 \\
Operation performance & 3.80 & 0.277 & 3 \\
Long-term relationship & 3.95 & 0.273 & 4 \\
\hline
\end{tabular}

\section{Conclusion}

With 200 firms interviewed, who use logistics services and application of the main quantitative method of statistical models, interesting findings show that firm with different sizes have different demands toward logistics services. There are key factors impacting on firm's 3PL selection, e.g. cost of service, reputation, operation performance, and long-term relationship, in which they are mostly depended on cost of service. This means that they agree with the best choice depended on cost of service of 3PL providers. Reputation is concerned as the second ranking, operation performance of 3PL provider as the third ranking and long-term relationship as the fourth ranking. Unluckily, there is no evidence to confirm financial performance of 3PL providers which is considered by firm toward selection. This case is not surprised, because financial performance of the provider is internal information, it isn't easy to let its customer know that.

Findings are a great reference for policy makers to think of solutions of how to support logistics service sector. Because this activity is very fundamental to stimulate economic development of a country. Doing that, the needed integration of systems and services should be considered to become a capable source of both systems and services integration for their customers. In addition, 3PL providers should focus on improving quality of manpower, investing in IT to improve the tracking and tracing ability and enhancing integration, connectivity with in bound and out bound 3PL provider in order to optimize operating and widen global capability.

\section{References}

Aguezzoul, A. (2012). Overview on supplier selection of goods versus 3PL selection. Journal of Logistics Management, 3(1), 18-23.

Bagchi, P., \& Virum, H. (1998). Logistical alliances-Trends and prospects in integrated Europe. Journal of Business Logistics, 19(1), 191-213.

Banomyong, R. (2005). The impact of port and trade security initiatives on maritime supply-chain management. Maritime Policy \& Management, 32(1), 3-13.

Bhatnagar, R., Sohal, A. S., \& Millen, R. (1999). Third party logistics services: A Singapore perspective. International Journal of Physical Distribution \& Logistics Management, 29(9), 569-587.

Bowersox, D. J., \& Daugherty, P. J. (1987). Emerging patterns of logistical organization. Journal of Business Logistics, 8(1), 46-60.

Boyson, S., Corsi, T., Dresner, M., \& Rabinovic, E. (1999). Managing effective third party logistics relationships: What does it take? Journal of Business Logistics, 20(1), 73-100.

Dapiran, P., Lieb, R., Millen, R., \& Sohal, A. (1996). Third party logistics service usage by large Australian firms. International Journal of Physical Distribution \& Logistics Management, 26(10), 36-45. 
Farahani, R., Rezapour, S., \& Kardar, L. (2011). Logistics operations and management: Concepts and models (1st ed.). Elsevier. Hair, J. F., Black, W. C., Babin, B. J., \& Anderson, R. E. (2010). Multivariate Data Analysis (7th ed.). Prentice Hall.

Hertz, S., \& Aldredsson, M. (2003). Strategic Development of Third party Logistics Providers. Industrial Marketing Management, 32, 134-149.

Hertz, S., \& Alfredsson, M. (2003). Strategic development of third party logistics providers. Industrial Marketing Management, 32, 139-149.

Hwang, H. S., Moon, C., Chuang, C. L., \& Goan, M. J. (2005). Supplier selection and planning model using AHP. International Journal of the Information Systems for Logistics and Management, 1(1), 47-53.

Knemeyer, A. M., Corsi, T. M., \& Murphy, P. R. (2003). Logistics outsourcing relationships: Customer perspectives. Journal of Business Logistics, 24(1), 77-109.

Lieb, R., \& Randall, H. (1996). A comparison of the use of third party logistics services by large American manfacturers, 1991, 1994, and 1996. Journal of Business Logistics, 17(1), 305-320.

Marasco, A. (2008). Third-party logistics: A literature review. International Journal of Production Economics, 113, 127-147.

Meade, L., \& Sarkis, J. (2002). A conceptual model for selecting and evaluating third-party reverse logistics providers. Supply Chain Management: An International Journal, 7(5), 283-295.

Muller, E. (1993). Muller 1993. Distribution, July, 64-69.

Spencer, M. S., Rogers, D., \& Daugherty, P. J. (1994). JIT systems and external logistics suppliers. International Journal of Operations \& Production Management, 14(6), 60-74.

Thai, V. V., \& Grewal, D. (2005). An analysis of the efficiency and competitiveness of Vietnamese port system. Asia Pacific Journal of Marketing and Logistics, 9(2), 119-137. 